\title{
SYNTHESIS OF THE ZSM-5 ZEOLITE WITH MIXTURES BINARY OF TETRAETHYLAMMONIUM HYDROXIDE AND AMINES AS ORGANIC STRUCTURE DIRECTING AGENTS
}

\section{SÍNTESE DA ZEÓLITA ZSM-5 COM MISTURAS BINÁRIAS DE HIDRÓXIDO DE TETRAETILAMÔNIO E AMINAS COMO AGENTES ORGÂNICOS DIRECIONADORES DE ESTRUTURA}

\author{
D. P. S. SILVA*, B. J. B. SILVA and A. O. S. SILVA
}

Federal University of Alagoas, Department of Chemical Engineering, Technology Center, Maceió, AL, Brazil.

${ }^{*}$ Diogo Pimentel de Sá da Silva, Federal University of Alagoas, Department of Chemical Engineering, Maceió, AL, Brazil, Phone: +5582999699670 e-mail address: diogo.silva@ctec.ufal.br (D.P.S. Silva).

\begin{tabular}{l} 
A R T I C L E I N F O \\
\hline Article history: \\
Received 2020-07-02 \\
Accepted 2020-09-04 \\
Available online 2020-09-04 \\
p a la vras - ch a ve \\
ZSM-5 \\
Agente direcionador de estrutura \\
Misturas binárias de orgânicos \\
keywords \\
ZSM-5 \\
Structure direction agents \\
Binary mixtures of organic
\end{tabular}

Binary mixtures of organic

\begin{abstract}
A B S T R A C T
Among the microporous materials used in heterogeneous catalysis, zeolites have become promising due to the relevant physicochemical and catalytic properties. Noteworthy is the zeolite ZSM-5 used as a catalyst in reactions in the areas of petrochemical and fine chemistry, such as cracking, isomerization, alkylation and aromatization reactions of olefins. In view of this, the objective of this work was to synthesize the ZSM-5 zeolite, through binary mixtures of tetraethylammonium hydroxide (TEAOH) and different amines (n-butylamine, isobutylamine and diisobutylamine) acting as organic structure directing agents (SDA's). $X$ ray diffractometry indicated that only the reaction system containing TEAOH and $n$ butylamine provided the achievement of highly crystalline ZSM-5 and without competing phases. The nitrogen adsorption-desorption isotherms indicated that a material with a high surface area $\left(329 \mathrm{~m}^{2} \cdot \mathrm{g}^{-1}\right)$ and pore volume $\left(0.26 \mathrm{~cm}^{3} \cdot \mathrm{g}^{-1}\right)$ was obtained. Thus, it was possible to identify a new synthesis route in obtaining the ZSM-5 zeolite.

R E S U M O
\end{abstract}

Dentre os materiais microporosos utilizados na catálise heterogênea, as zeólitas tornaramse promissoras devido às pertinentes propriedades físico-químicas e catalítica. Destacandose a zeólita ZSM-5utilizada como catalisador em reações nas áreas de petroquímica e química fina, como as reações de craqueamento, isomerização, alquilação e aromatização de olefinas. Diante disto, o objetivo deste trabalho foi sintetizar a zeólita ZSM-5, através de misturas binárias de hidróxido de tetraetilamônio (TEAOH) e diferentes aminas (nbutilamina, isobutilamina e diisobutilamina) atuando como agentes orgânicos direcionadores de estrutura (OSDA'S). A difratometria de raios $X$ indicou que apenas o sistema reacional contendo TEAOH e n-butilamina proporcionou à obtenção da ZSM-5 altamente cristalina e isenta de fases concorrentes. As isotermas de adsorção-dessorção de nitrogênio indicaram a obtenção de um material com elevada área superficial $\left(329 \mathrm{~m}^{2} \cdot \mathrm{g}^{-1}\right) e$ volume de poros $\left(0,26 \mathrm{~cm}^{3} \cdot \mathrm{g}^{-1}\right)$. Dessa forma, foi possivel identificar uma nova rota de síntese na obtenção da zeólita ZSM-5. 


\section{INTRODUCTION}

Zeolites are complex inorganic polymers and crystalline, based on a three-dimensional arrangement, compound of tetrahedrons $\mathrm{TO}_{4}(\mathrm{~T}=\mathrm{Si}$ or $\mathrm{Al})$ interconnected through a common oxygen atom (Englert and Rubio, 2005). In this configuration, negative charges of $\mathrm{AlO}_{4}^{-}$tetrahedrons are compensated by cations (alkaline and alkaline earth) and set up a structure, with channels, allowing the ion exchange and a reversible hydration. It is usual the addition of organic compounds (quaternary cations and amines) as structuredirection agents (SDA's) and load balancing agent to get highly crystalline zeolites (Shinzato, 2007).

Due to the intrinsic properties of zeolites, as crystallinity, large surface area, acidity, ion exchange and selectivity, zeolites are used in a variety of applications such as: gas separation process, catalysis, adsorbents and ion exchangers of high capacity and selectivity (Chen et al., 2018). The catalytic activity and significant selectivity of zeolitic materials are attributed to the large internal surface area and distribution of active sites which are accessible through uniform size pores, high thermal resistance, chemical inertness, and high mechanical resistance (Bayati et al., 2008).

The ZSM-5 (Zeolite Socony Mobil, being "5" the opening of the zeolite pores, in angström) is a zeolite which is characterized by the high silicon content in the structure ( $\mathrm{Si} / \mathrm{Al}$ ratio between 11 and infinite), belongs to the group of the pentasil family and has MFI-type of structure according to the classification proposed by the International Zeolite Association (IZA) (Song et al., 2013). The ZSM-5 has many industrial applications due to its high selectivity in certain reactions catalytic and high degree of thermal and acid stability. Therefore, ZSM-5 is widely used as a catalyst in the petrochemical industry in isomerization, alkylation, and aromatization process (Cheng et al., 2008).

The most used method for the synthesis of ZSM-5 zeolites is hydrothermal crystallization, which corresponds to conversion of a mixture of silicon and aluminum compounds, alkali metal cations, organic molecules, and water in a crystalline microporous aluminosilicate. The gel that is formed is placed in an autoclave and heated for a period of time. The effects of different factors, such as: raw materials, gel composition, mixing procedure, $\mathrm{pH}$, aging condition, agitation, synthesis temperature, synthesis time, and, mainly, the amount and kind of the SDA, influence the selectivity of the process for the crystallization of a certain material (Suzuki et al., 2009).

The molecules of the SDA significantly affect the crystallization of the zeolites by: (i) influencing the gelation and/or nucleation processes, where the $\mathrm{TO}_{4}(\mathrm{~T}=\mathrm{Si}$ or $\mathrm{Al})$ units are organized in a particular geometry around themselves and, as a result, provide forerunner species for subsequent nucleation or crystal growth, (ii) contributes to the stability when new interactions happen (hydrogen bonds, electrostatic and London dispersion interactions) (Zhang et al., 2012) and (iii) decreasing the chemical potential of the network formed through the inclusion of the organic template agent during the synthesis (Lejka et al., 2007).
Given the above, it is evident that adding SDA to the reaction medium, which is used for the zeolites synthesis, has a fundamental role in determining the structure that will be used during the crystallization process. Thus, this work evaluated the effect of textural properties of ZSM-5 zeolites synthesized in reaction systems, containing binary mixtures of SDA. The role of the addition of tetraethylammonium hydroxide and amines (n-butylamine, isobutylamine and diisobutylamine) was analyzed in order to get the type of crystallization phase obtained, the crystallization rate and the effect of the reactional mixture composition over the formation process of the zeolitic materials. All samples were characterized by X-ray diffraction (XRD) and the most crystalline sample underwent characterized by thermal analysis (TG/DTG) and nitrogen adsorption-desorption.

\section{EXPERIMENTAL}

\subsection{Reagents}

The following reagents were used: sodium silicate (Quimesp, 29.6\% $\mathrm{SiO}_{2}, 9.2 \% \mathrm{Na}_{2} \mathrm{O}$ ) as a silicon and sodium source, sodium hydroxide (Sigma-Aldrich, 98\%) as a sodium source; aluminum sulfate octadecahydrate (Merck, 99\%) as a aluminum source, sulfuric acid (Sigma-Aldrich, 98\%) to adjust the basicity of the reactional medium, distilled water and tetraethylammonium hydroxide (Sigma-Aldrich, 40\%), nbutylamine (Vetec, 98\%), isobutylamine (Sigma-Aldrich, 99\%) and diisobutylamine (Sigma-Aldrich, 99\%) as a organic structure directing agents.

\subsection{Synthesis of the ZSM-5 zeolite}

The compositions and the procedure for preparing the synthesis gels were based on the classic hydrothermal method (Szostak, 1998). The precursor reagents were mixed containing the following molar composition: $0.2 \mathrm{TEAOH}: 0.8 \mathrm{AMINE}$ : $1 \mathrm{SiO}_{2}: 0.01 \mathrm{Al}_{2} \mathrm{O}_{3}: 0.3 \mathrm{Na}_{2} \mathrm{O}: 20 \mathrm{H}_{2} \mathrm{O}: 0.3 \mathrm{H}_{2} \mathrm{SO}_{4}$.

The process of mixing the precursor materials was performed in stages: (i) dissolving the sodium silicate in $40 \%$ of water, then adding the aluminum sulfate octadecahydrate, under stirring for 20 minutes (solution A), (ii) dilution of sulfuric acid in $60 \%$ of water and the addition of SDA (TEAOH and amine), under stirring for 20 minutes (solution $\mathrm{B}$ ), (iii) mixing of solutions $\mathrm{A}$ and $\mathrm{B}$, under stirring for 30 minutes. After preparing the gel, it was transferred to teflon vessels coated in stainless steel autoclaves and heated in oven at $170{ }^{\circ} \mathrm{C}$ for 24 to 96 hours. The resulting solid was separated by vacuum filtration, being washed with distilled water until it reached neutral $\mathrm{pH}$, and then dried in an oven at $120^{\circ} \mathrm{C}$ for 12 hours. The catalysts were calcined under an air flow of 100 $\mathrm{mL} \cdot \mathrm{min}^{-1}$ with a heating ramp of $2^{\circ} \mathrm{C} \cdot \mathrm{min}^{-1}$ to $550^{\circ} \mathrm{C}$ for 6 hours.

\subsection{Characterization}

The XRD analyzes were performed using a Shimadzu XRD-6000 diffractometer, with CuKU $(\boldsymbol{r}=0.1542 \mathrm{~nm}), \mathrm{Ni}$ filter, $40 \mathrm{kV}$ voltage and $30 \mathrm{~mA}$ current. The data was obtained

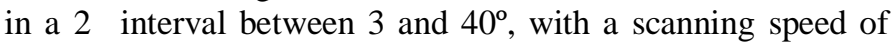
$2^{\circ} \mathrm{C} \cdot \mathrm{min}^{-1}$ and a step of $0.02^{\circ}$. The thermal analysis (TG/DTG) were performed in a Shimadzu DTG-60H thermobalance, with 
heating rate at $10^{\circ} \mathrm{C} \cdot \mathrm{min}^{-1}$, under an atmosphere of synthetic air of $100 \mathrm{~mL} \cdot \mathrm{min}^{-1}$, at room temperature at $800{ }^{\circ} \mathrm{C}$. Nitrogen adsorption-desorption measures were used in the Micromeritics ASAP 2020 equipment, in a range of $\mathrm{P} / \mathrm{P}_{0}$ relative pressure between 0.01 and 1.0 .

\section{RESULTS AND DISCUSSION}

At first, syntheses of catalytic materials were executed using only one of the organic templates (quaternary ammonium cation or one of the amines). Subsequently, the syntheses of the materials were made with mixtures of
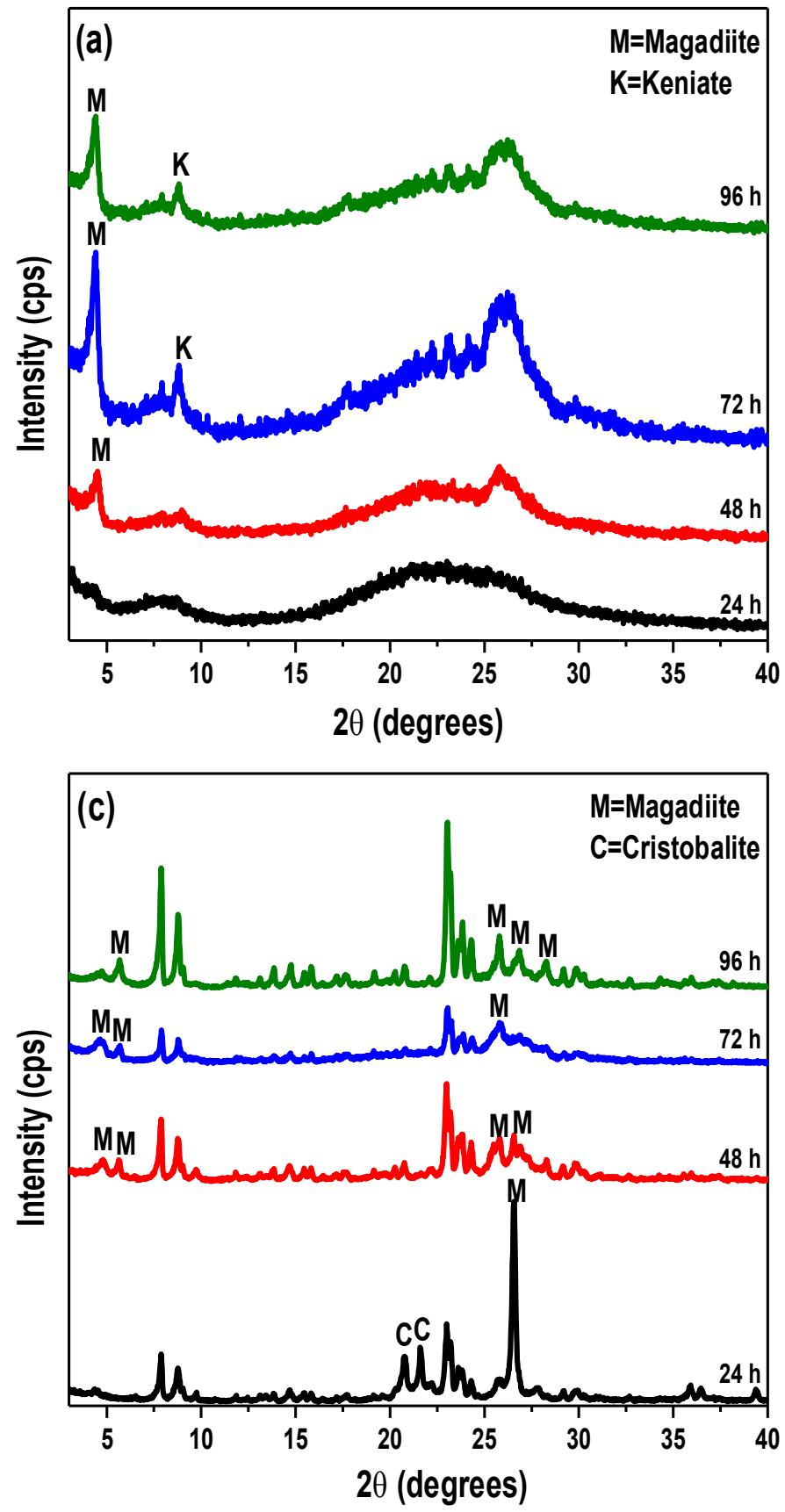

TEAOH and amines (isobutylamine, n-butylamine and diisobutylamine). As presented by Nishi and Thompson (2002), the reason for this methodology is to analyze which of the template or the mixture of these presents the best interaction in the reaction system, providing a better medium for the formation of the desired material.

The Figure 1 shows the comparison among diffractograms obtained from samples synthesized using only one of the SDA, at different times.

From the diffractograms presented in Figure 1 (a) it turns out that there is no formation of crystalline phases with 24 hours, however, with $48 \mathrm{~h}$, there is an appearance of diffraction peaks attributed to the Magadiite lamellar phase (JCPDS N ${ }^{\circ} 42-1350$ ) and, after 72 hours, the presence of the
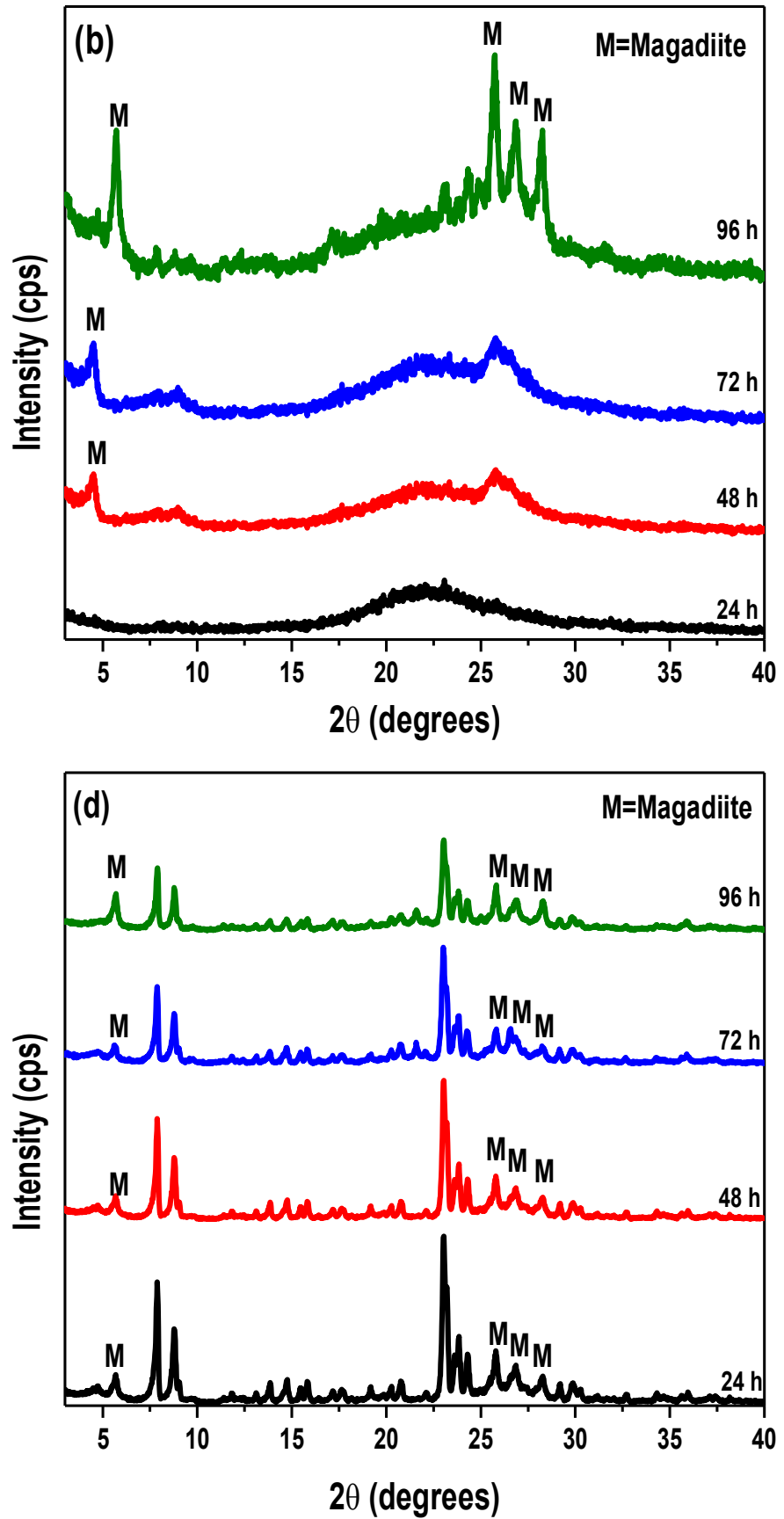

Figure 1 - XRD patterns the synthesis of (a) TEAOH, (b) diisobutylamine, (c) isobutylamine and (d) n-butylamine as SDA's at different times. 
Magadiite and Keniate phases (JCPDS N ${ }^{\circ} 20-1157$ ) is verified. The XRD in Figure 1 (b) demonstrate that within 24 hours there were amorphous phases and after 48 hours the formation of the Magadiite lamellar phase occurs.

Figures 1 (c) and (d) show the diffractograms of the samples synthesized with isobutylamine and n-butylamine, respectively, as an SDA, which showed, in all periods of crystallization, materials are obtained with the coexistence of the ZSM-5 phase (JCPDS $\mathrm{N}^{\circ}$ 42-0023) and the Magadiite lamellar phase. Studies report the synthesis of Magadiite with the $\mathrm{SiO}_{2}: \mathrm{NaOH}$ ratio in the range of 1.0: 0.2 to 1.0:9.0, where the $\mathrm{SiO}_{2}: \mathrm{NaOH}$ ratio used in this work was 1.0: 0.3 , so the amount of $\mathrm{NaOH}$ used may have favored the formation of Magadiite, leading to the formation of several segregated areas classified in zeolitic and lamellar regions (Ozawa et al., 2010; $\mathrm{Xu}$ et al., 2015). However, in Figure 1 (c) with $24 \mathrm{~h}$ of crystallization, ternary mixtures were obtained with the emergence of the Cristobalite phase (JCPDS $\mathrm{N}^{\circ}$ 82-0512) concomitantly with the Magadiite and ZSM-5 phases. The formation of cristobalite has been attributed to high levels of SAR $\left(\mathrm{SiO}_{2} / \mathrm{Al}_{2} \mathrm{O}_{3}>50\right)$ (Möller and Bein, 2011).

Figure 2 illustrates the XRD profiles of samples synthesized using mixtures of TEAOH and amines at different times.
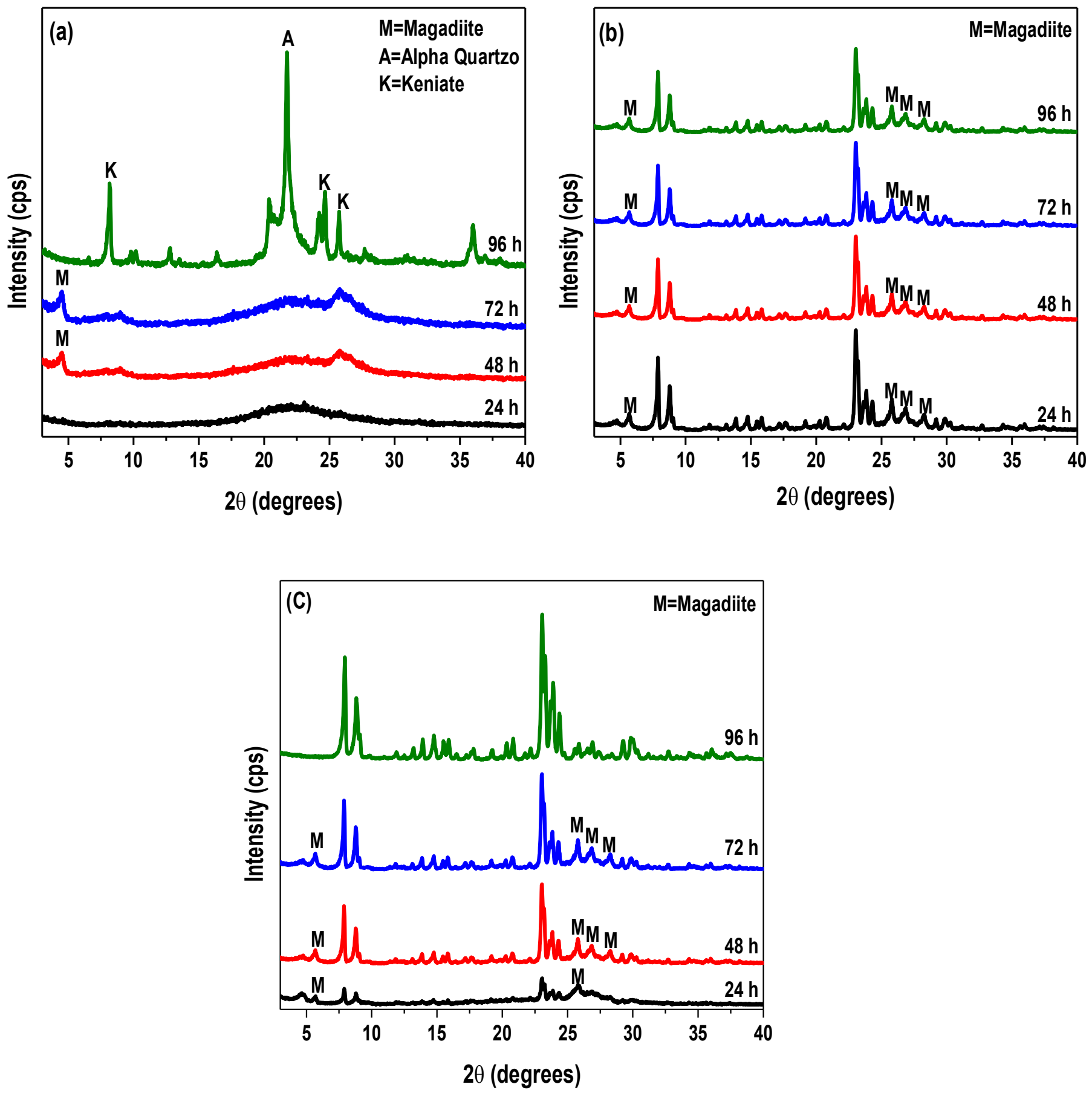

Figure 2 - XRD patterns using binary mixtures of TEAOH and (a) diisobutylamine, (b) isobutylamine, (c) n-butylamine as SDA's at different times. 
Figure 2 (a) shows the diffractograms of the samples synthesized with binary mixtures of TEOH and isobutylamine, where there was no formation of crystalline phases within 24 hours, occurring the appearance of diffraction peaks after 48 and 72 hours attributed to the Keniate lamellar phase. Lastly, within 96 hours, there is the formation of Magadiite lamellar phase concomitantly with the alpha quartz (JCPDS $\mathrm{N}^{\circ} 46-$ 1045) phase condensed.

Figure 2 (b) shows the diffractograms of the samples synthesized with binary mixtures of TEAOH and isobutylamine, which demonstrated, in all periods of crystallization, materials are obtained with the coexistence of the ZSM-5 and the Magadiite lamellar phase.

XRD on the Figure 2 (c) demonstrate that, up to 72 hours of crystallization, materials are obtained with the coexistence of ZSM-5 and the lamellar phase Magadiite, obtaining then the phase of ZSM-5 free of competing phases after 96 hours. From the reflections of presented by Bragg, it was found that the material obtained presented a diffractogram typical of this zeolite compared to the standard simulated XRD pattern of the MFI-IZA structure (Razavian and Fatemi, 2015). This indicates that the synthesis methods employed were effective for obtaining the ZSM-5 zeolite with the binary mixture of TEAOH and n-butylamine.

Figure 3 shows the TG/DTG curves of the ZSM-5 sample synthesized with a binary mixture of TEAOH and nbutylamine within 96 hours of crystallization. Through the DTG curves, four different mass loss events were identified. Therefore, being able to attribute them to: (I) and (II) of $25^{\circ} \mathrm{C}$ ï $360^{\circ} \mathrm{C}$, it comprises the loss of mass related to the elimination of the structural water (evaporation of hydroxyl groups weakly bound to the particles); (III) the region between $360{ }^{\circ} \mathrm{C}$ i $530{ }^{\circ} \mathrm{C}$, corresponds to the oxidative decomposition of ammonium ions from the SDAôs (Silva et al., 2008); (IV) above $530{ }^{\circ} \mathrm{C}$ the loss of mass is due to the coke deposited on the catalyst generated during the burning of the direction.

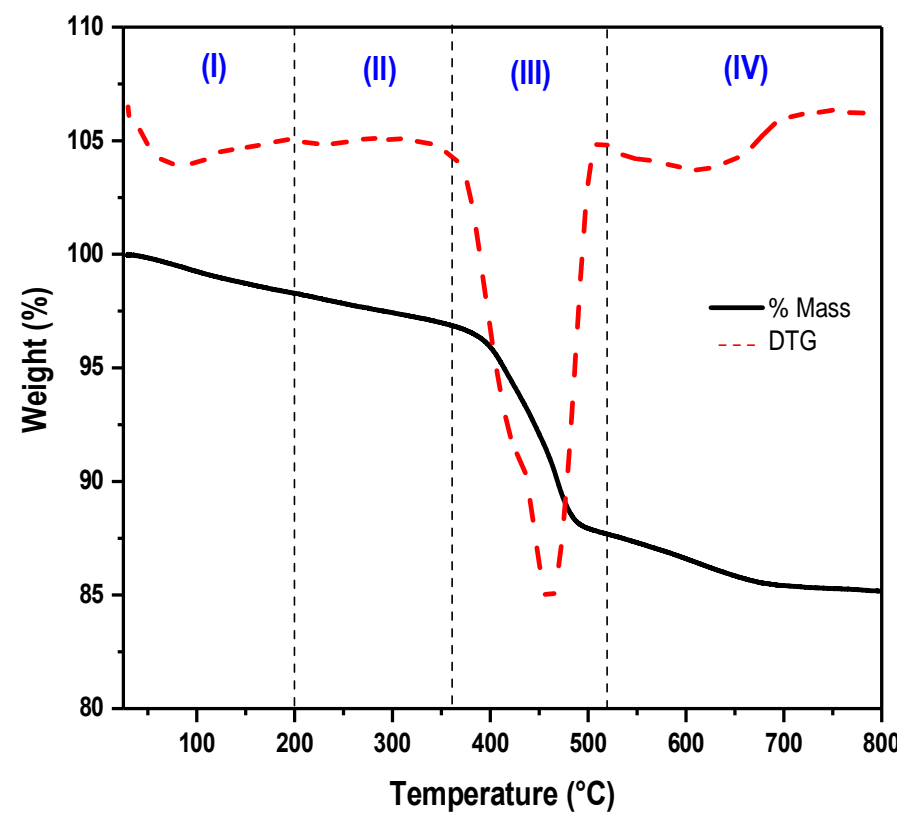

Figure 3 - Thermal analysis of zeolite ZSM-5 synthesized with a binary mixture of TEAOH and n-btutilamine with 96 hours of crystallization.
Figure 4 display the nitrogen adsorption-desorption isotherms of the ZSM-5 sample synthesized with a binary mixture of TEAOH and n-butylamine. According to the classification of the International Union of Pure and Applied Chemistry (IUPAC), this measure shows that the material obtained adsorbs nitrogen with a combination of type I isotherm, characteristic of microporous adsorbents, with that of type IV, characteristic of solids mesoporous with the presence of a hysteresis loop, which is related to the formation of pores in slit shapes (Senapati et al., 2014).

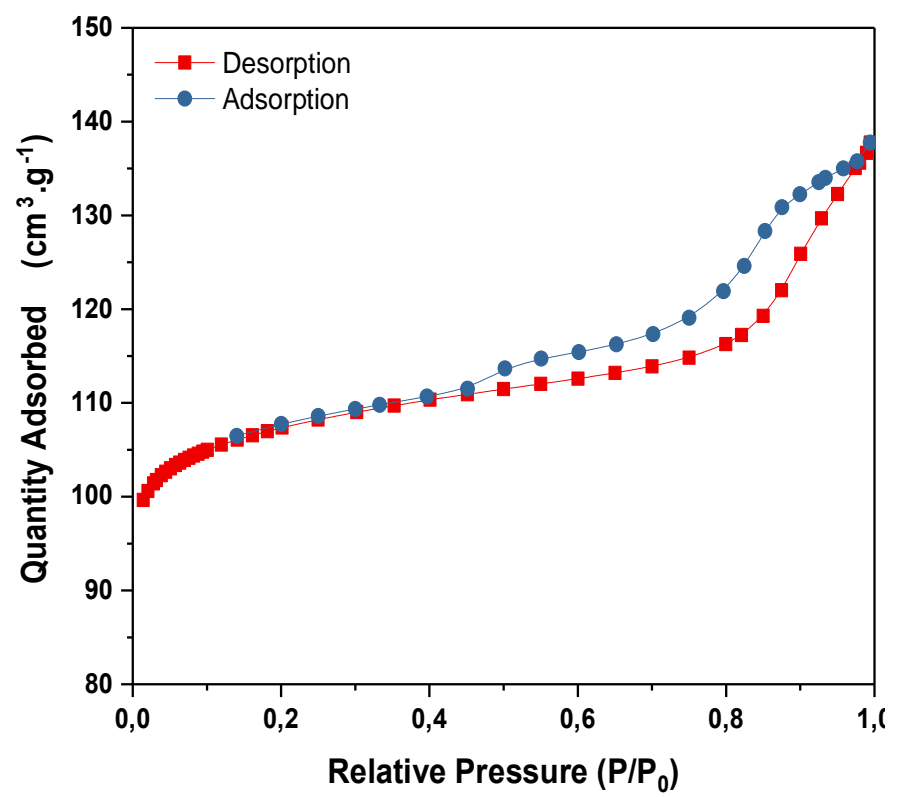

Figure 4 - $\mathbf{N}_{2}$ adsorption-desorption isotherms of the ZSM5 zeolite synthesized with a binary mixture of TEAOH and n-butylamine with 96 hours of crystallization.

Table 1 presents the data of the textural properties of the ZSM-5 synthesized with a binary mixture of TEAOH and n-butylamine with 96 hours of crystallization. The value of the specific area calculated by the BET method was high, characteristic of microporous solids, which is in agreement with values reported in the literature for zeolites of the ZSM-5types (Zhang et al., 2012; Yu, 2013). The presence of mesopores characterized by the hysteresis loop in the adsorption isotherm was confirmed by the pertinent volume of mesopores, which agrees with the hysteresis classification observed in Figure 4.

Table 1 - Textural properties of ZSM-5 synthesized with a binary mixture of TEAOH and n-butylamine with 96 hours of crystallization.

\begin{tabular}{ccccc}
$\begin{array}{c}\mathbf{A}_{\mathrm{BET}} \\
\left(\mathbf{m}^{\mathbf{2}} \cdot \mathbf{g}^{-\mathbf{l}}\right)\end{array}$ & $\begin{array}{c}\mathrm{A}_{\mathrm{EX}} \\
\left(\mathbf{m}^{\mathbf{2}} \cdot \mathbf{g}^{-\mathbf{l}}\right)\end{array}$ & $\begin{array}{c}\mathrm{A}_{\text {Micro }} \\
\left(\mathbf{m}^{\mathbf{2}} \cdot \mathbf{g}^{-\mathbf{l}}\right)\end{array}$ & $\begin{array}{c}\mathbf{V}_{\text {Total }} \\
\left(\mathbf{c m}^{\mathbf{3}} \cdot \mathbf{g}^{-\mathbf{l}}\right)\end{array}$ & $\begin{array}{c}\mathbf{V}_{\text {Micro }} \\
\left(\mathbf{c m}^{\mathbf{3}} \cdot \mathbf{g}^{-\mathbf{l}}\right)\end{array}$ \\
\hline 329 & 109 & 233 & 0.26 & 0.12
\end{tabular}

\section{CONCLUSION}

The XRD analysis indicated that only the reactional system containing a binary mixture of TEAOH and n- 
butylamine, such as SDAô, within 96 hours of crystallization, was possible to obtain ZSM-5, without the presence of contaminating phases. Nitrogen adsorption-desorption isotherms indicated that a material with a high surface area and mesoporous volume was obtained. Therefore, it was possible to identify a new synthesis route in obtaining the ZSM-5.

\section{A C K N O W L E D G M E N T S}

The authors are grateful for the financial support of the Coordenação de Aperfeiçoamento de Pessoal de Nível Superior (CAPES) and National Council for Scientific and Technological Development (CNPq/Brazil), through a research grant and the Petrobras.

\section{R E F E R E N C E S}

BAYATI, B.; BABALUO, A. A.; KARIMI, R. Hydrothermal synthesis of nanostructure NaA zeolite: The effect of synthesis parameters on zeolite seed size and crystallinity. Journal of the European Ceramic Society, v. 28, p. 2653ї 2657, 2008. Available at: <https://www.sciencedirect.com/science/article/abs/pii/ S0955221908001878>. Accessed on May 20 $0^{\text {th }}, 2020$.

CALDEIRA, V. P., SANTOS, A. G., PERGHER, S. B., COSTA, M. J., ARAUJO, A. S. Use of a low-cost template-free ZSM-5 for atmospheric petroleum residue pyrolysis. Química Nova, v. 39, n. 3, p. 292-297, 2016. Available at: <https://www.scielo.br/scielo.php?pid=S0 $10040422016000300292 \&$ script $=$ sci_arttext $>$.Accessed on May $22^{\text {th }}, 2020$.

LEJKA, J., VAN BEKKUM, H., CORMA, A., SCHUETH, F. Introduction to zeolite molecular sieves. Elsevier, $3^{\text {st }} \mathrm{ed}$, 2007.

CHEN, Y.; LI, C.; CHEN, X.; LIU, Y.; LIANG, C. Synthesis of ZSM-23 zeolite with dual structure direting agents for hydroisomerization of n-hexadecane. Microporous and Mesoporous Materials, v. 268, p. 216224, 2018. Available at: <https://www.sciencedirect.co $\mathrm{m} /$ science/article/abs/pii/S138718111830218X>. Accessed on May $21^{\text {th }}, 2020$.

CHENG, Y., LIAO, R. H., LI, J. S., SUN, X. Y., \& WANG, L. J. Synthesis research of nanosized ZSM-5 zeolites in the absence of organic template. Journal of materials processing technology, v. 206, p. 445-452, 2008. Available at: <https://www.sciencedirect.com/science /article/abs/pii/S0924013607014173>. Accessed on May $20^{\text {th }}, 2020$.

ENGLERT, A. H.; RUBIO, J. Characterization and environmental application of a chilean natural zeólita. International Journal of Mineral Processing, v. 75, p. 21-29, 2005. Available at: <https:/www.sciencedirect .com/science/article/abs/pii/S0301751604000067>. Accessed on May 20 $0^{\text {th }}, 2020$.

MÖLLER, K., BEIN, T. Crystallization and porosity of ZSM23. Microporous and Mesoporous Materials, v. 143 , n. 2, p. 253 ï 262, 2011. Available at: <https:/www.sci encedirect.com/science/article/abs/pii/S1387181110004 $52 X>$. Accessed on May $23^{\text {th }}, 2020$.

NISHI, K., THOMPSON, R. W. Synthesis of classical zeolites. Handbook of porous solids, p. 736-814, 2002.
Available at: <https://onlinelibrary.wiley.com/doi/abs /10.1002/9783527618286.ch18adoi/abs/10.1002/97835 27618286.ch18a>. Accessed on May 22 ${ }^{\text {th }}, 2020$.

OZAWA, K.; OKADA,R.; NAKAO, Y.; OGIWARA, T.; ITO H, H.; ISO, F. Hydrothermal Synthesis of Magadiite/Si-ZSM-11 Composites, Journal of the American Ceramic Society, v. 93, n. 12, p. $4022 i$ 4025, 2010.

Available at: <https://ceramics.onlinelibrary.wiley.com /doi/abs/10.1111/j.1551-2916.2010.04229.x>. Accessed on May $21^{\text {th }}, 2020$.

RAZAVIAN, M.; FATEMI, S. Synthesis and application of ZSM-5/SAPO-34 and SAPO-34/ZSM-5 composite systems for propylene yield enhancement in propane dehydrogenation process. Microporous and Mesoporous Materials, v. 201, p. 176 ï 189, 2015. Available at: < https://www.sciencedirect.com/ science/article/abs/pii/S1387181114005253>. Accessed on May $26^{\text {th }}, 2020$.

SENAPATI, S., ZIMDARS, J., REN, J., KOLLER, H. Postsynthetic modifications of as-made zeolite frameworks near the structure-directing agents. Journal of Materials Chemistry A, v. 2, n. 27, p. 10470-10484, 2014. Available at: < https://pubs.rsc.org/en/content/art iclelanding/2014/ta/c4ta00656a/unauth\#!divAbstract>. Accessed on May 22 2020.

SHINZATO, M. C. Remoção de metais pesados em solução por zeólitas naturais: Revisão Crítica. Revista do Instituto Geológico, v. 27, n. 2, p. 65-78, 2007. Available at: < http://www.ppegeo.igc.usp.br/index.php $/$ rig/article/view/8911>. Accessed on May $27^{\text {th }}, 2020$.

SILVA, J. B.; RODRIGUES, J. A. J.; NONO, M. DO C. A. Caracterização de materiais catalíticos. 2008. 69 f. PósGraduação em Engenharia e Tecnologia Espaciais, Instituto Nacional de Pesquisas Espaciais, São José dos Campos ï SP, 2008.

SONG, Z., LIU, W., CHEN, C., TAKAHASHI, A., FUJITANI, T. Production of propylene from ethanol over ZSM-5 co-modified with zirconium and phosphorus. Reaction Kinetics, Mechanisms and Catalysis, v. 109, n. 1, p. 221-231, 2013. Available at: <https://link.springer.com/article/10.1007/s11144-013 0546-5>. Accessed on May 22 $2^{\text {th }}, 2020$.

SUZUKI, Y.; WAKIHARA, T.; ITABASHI, K.; OGURA, M.; OKUBO, T. Cooperative effect of sodium and potassium cations on synthesis of ferrierite. Topics in Catalysis, v. 52, p. 67-74. 2009. Available at: <https://link.springer.com/article/10.1007\%2Fs1124400 8-9136-6 >. Accessed on May 27 $7^{\text {th }}, 2020$.

SZOSTAK, R., Molecular Sieves: Principles of Synthesis and Identification, $2^{\text {sto }}$ ed., Blackie Academic \& Professional, London, 1998.

XU, B.; ZHU, X.; CAO, Z.; YANG, L.; YANG, W. Catalytic oxidative dehydrogenation of n-butane over $\mathrm{V}_{2} \mathrm{O}_{5} / \mathrm{MO}$ $\mathrm{Al}_{2} \mathrm{O}_{3}(\mathrm{M}=\mathrm{Mg}, \mathrm{Ca}, \mathrm{Sr}, \mathrm{Ba})$ catalysts. Chinese Journal of Catalysis, v. 36, n. 7, p. 1060ї 1067, 2015. Available at: < https://www.sciencedirect.com/science/article/abs/ pii/S1872206715608397>. Accessed on May 25 ${ }^{\text {th }}, 2020$.

YU, Q., MENG, X., LIU, J., LI, C., CUI, Q. A fast organic template-free, ZSM-11 seed-assisted synthesis of ZSM5 with good performance in methanol-to-olefin. Microporous and mesoporous materials, v. 181, p. 192-200, 2013. Available at: <https://www.sciencedire 
ct.com/science/article/abs/pii/S1387181113003703>. Accessed on May 23 $3^{\text {th }}, 2020$.

ZHANG, L.; YANG, W.; LIU, Y.; LIANG, C. Organic template-free synthesis of ZSM-5/ZSM-11 cocrystalline zeolite. Microporous and Mesoporous Materials, v. 147, n. 1, p. 117-126, 2012. Available at: <https://www.sciencedirect.com/science/article/abs/pii/ S1387181111002630>. Accessed on May 23 ${ }^{\text {th }}, 2020$. 